$\underline{\text { Research Article }}$

\title{
Cardiovascular Outcomes in High-Risk Patients Undergoing OPCAB Surgery Compared to Traditional CABG
}

\section{Analisis Luaran Kardiovaskular Pasien Risiko Tinggi pada Operasi OPCAB Dibandingkan CABG Tradisional}

\author{
Widya Trianita S, Dudy Arman H, Sugisman \\ National Cardiovascular Center Harapan Kita Jakarta
}

\begin{abstract}
The benefit of coronary artery bypass graft (CABG) for coronary artery disease (CAD) with Ejection Fraction (EF) $30 \%$ and ischemic burden (IB) $10 \%$ is still debatable. The objective of this study is to analyze mortality and morbidity in patients with EF $30 \%$ and ischemic burden 10\% undergoing OPCAB compared to traditional CABG (TCABG). The retrospective analytic cohort study was performed using data from January 2015-November 2018 at National Cardiovascular Center Harapan Kita Jakarta, Indonesia. 109 patients were included. 35 patients undergoing OPCAB and 74 patients undergoing TCABG. The primary outcomes were mortality rate, morbidity rate, and length of stay. Arrhythmia is statistically lower in OPCAB compared to TCABG (8.6\% vs 39.2\%; $p=0.001)$. Kidney injury is statistically lower in OPCAB (8.6\% vs $27.0 \% ; p=0.027)$. Stroke is statistically lower in OPCAB (1.0\% vs $17.6 \% ; p=0,032)$. There is no significant difference between OPCAB and TCABG in mortality, $5.7 \%$ vs $16.2 \%$, ( $R R=3.20 ; C I 95 \%=0.67-15.12 ; p=0.126)$. There was a statistically significant difference in the occurrence of postoperative morbidity in CAD patients with $E F \leq 30 \%$ and $I B \leq 10 \%$ who underwent OPCAB surgery compared with patients who underwent TCABG. Mortality that occurred after OPCA $\bar{B}$ procedure was lower in $C A D$ patients with $E F \leq 30 \%$ and $I B \leq 10 \%$ compared to TCABG although the statistical difference was not significant. Therefore, patients with this condition are more advisable to undergo OPCAB.
\end{abstract}

Keyword: Ischemic burden, left ventricular dysnfunction, off-pump coronary artery bypass grafting

\begin{abstract}
ABSTRAK
Manfaat Coronary Artery Bypass Grafting (CABG) pada pasien penyakit jantung koroner (PJK) EF 30\% dan ischemic burden $10 \%$ masih diperdebatan. Off-pump CABG (OPCAB) diharapkan mengurangi komplikasi mesin cardiopulmonary bypass (CPB). Penelitian ini untuk menganalisa mortalitas dan morbiditas pasien dengan EF $30 \%$ dan ischemic burden $10 \%$ pasca OPCAB dibandingkan Conventional CABG (CCABG). Dalam penelitian retrospektif ini, terdapat subjek penelitian sebanyak 109 pasien yang terdiri dari 35 pasien kelompok OPCAB dan 74 pasien kelompok CCABG di Rumah Sakit Jantung dan Pembuluh Darah Harapan Kita selama bulan Januari 2015 - November 2018. Aritmia pada kelompok OPCAB bermakna secara statistik lebih rendah dibandingkan kelompok CCABG ( $R R=3,55 ; 95 \% \mathrm{Cl}=1,40-8,91 ; p=0,012)$. Gagal ginjal juga bermakna secara statistik lebih rendah pasca OPCAB ( $R R=3,96 ; 95 \% \mathrm{Cl} 1,09-14,35 ; \mathrm{p}=0,027)$. Stroke pasca prosedur OPCAB juga bermakna secara statistik lebih rendah ( $R R=7,25 ; 95 \% \mathrm{Cl}=1,91-57,81 ; p=0,032)$. Hal lainnya adalah sepsis pasca prosedur OPCAB bermakna secara statistik lebih rendah dibandingkan CCABG $(5,7 \%$ vs $21,6 \%, R R=0,037 ; 95 \%$ $\mathrm{Cl}=0,67-15,12 ; \mathrm{p}=0,037)$. Namun mortalitas pasca teknik OPCAB dibandingkan CCABG tidak bermakna secara statistik, 5,7\% dibandingkan 16,2\%, ( $R R=3,20 ; 95 \% \mathrm{Cl}=0,67-15,12 ; \mathrm{p}=0,126)$. Kami merekomendasikan OPCAB pada pasien PJK EF $30 \%$ dan ischemic burden $10 \%$.
\end{abstract}

Kata Kunci: Disfungsi ventrikel kiri, ischemic burden, off-pump coronary artery bypass grafting

Correspondence: Widya Trianita S. National Cardiovascular Center Harapan Kita, Jl. Lt. Gen. S. Parman Kav 87 Slipi Jakarta Barat 11420 Tel.081287770330Email:wdya.trianita@gmail.com

DOI: http://dx.doi.org/10.21776/ub.jkb.2021.031.04.9 


\section{INTRODUCTION}

Single photon emission computed tomography (SPECT) is regularly used to assess myocardial viability and ischemic burden before CABG (1). Ischemic burden shows the amount of ischemic-induced myocardium which can still improve at rest. The benefit of revascularization in patients with $\mathrm{EF} \leq 30 \%$ and ischemic burden $\leq 10 \%$ remains questionable because of the high risks of postoperative mortality and morbidity. Furthermore, ischemic burden $\leq 10 \%$ reveals that only a small amount of myocardial ischemia improves at rest (2). However, myocardial ischemia that does not enhance at rest is due to either myocardial necrosis or myocardium stunning or hibernation (3).

CABG procedures can be performed using a cardiopulmonary bypass (CPB) machine, referred to as traditional coronary artery bypass grafting (TCABG), or without utilizing a CPB machine, termed as off-pump coronary artery bypass grafting (OPCAB). To date, there are no guidelines available for the selection of surgical techniques that can reduce postoperative mortality and morbidity in CAD patients with $\mathrm{EF} \leq 30 \%$ and ischemic burden $\leq 10 \%$ with high perioperative risks. Many surgical specialists prefer TCABG to OPCAB, following that hemodynamic instability, hypotension, or sudden cardiac arrest are common problems in this group of patients $(4,5)$. Surgery with the TCABG technique makes it easier for surgeons in performing coronary artery anastomosis due to heart immobility (4). The CPB machine and administration of cardioplegic fluid to stop the heart from beating provide a bloodless surgical field, without the movement of the heart muscle during CABG procedures. However, any contact with the CPB machine will cause a systemic inflammatory response and coagulopathy and potentially induce dysfunction of various organs, myocardial ischemia, and edema which further reduce myocardial function, thus increasing the risks of postoperative morbidity and mortality $(4,6)$. The OPCAB procedure performed without using the CPB machine is expected to reduce such risks.

The purpose of this study was to compare the characteristics and the clinical outcomes between OPCAB and TCABG in patients with EF $30 \%$ and ischemic burden $10 \%$. The results would help surgeons to decide which procedure is the best option for patients with this condition.

\section{METHOD}

This study used a retrospective analytic cohort study design to determine mortality and morbidity in 109 CAD subjects with $\mathrm{EF} \leq 30 \%$ and ischemic burden $\leq 10 \%$, by comparing OPCAB with TCABG over a period of January 2015 to November 2018 at the Harapan Kita National Cardiovascular Heart Center and by satisfying the study's inclusion and exclusion criteria. The inclusion criteria of this study were CAD subjects with $E F \leq 30 \%$ \& ischemic burden $\leq 10 \%$ who underwent elective CABG procedures, while the exclusion criteria were CAD subjects with ischemic burden $\leq 10 \%$ who underwent emergency or urgent CABG procedures, CAD subjects with concomitant ruptured ventricular septum, CAD subjects accompanied by heart valve disease with moderate to severe degree requiring intervention that had been confirmed by echocardiography examination, and subjects with cardiac surgery other than CABG procedures. The study was conducted by taking the medical record data of the patients involved after obtaining permission from the research ethics committee of the Harapan Kita National Cardiovascular Heart Center.

\section{Statistical Analysis}

All data were analyzed using SPSS for Macintosh version 20.0 (SPSS, Inc. Chicago, Illnois). In the univariate analysis, nominal data were presented as proportions and frequencies in descriptive tables or narratives and tested using the Kolmogorov Smirnov test for normality test. Pearson's chi-square was applied for nominal variables and Student's T-test for continuous variables. For the bivariate analysis, Chi-Square test was performed with a $2 \times 2$ table and Relative Risk (RR) analysis. To assess the relationship of numerical dependent variables based on the categorical independent variables, a t-test was carried out when the data were normally distributed. However, when the data were not normally distributed, the MannWhitney test was conducted. Test results with $p$-value $<0.05$ were considered statistically significant.

\section{RESULTS}

\section{Baseline of Operative Characteristics of Patients}

The baseline characteristics of 109 patients who underwent OPCAB and TCABG are described in Table 1. The results indicated that there were no statistically significant differences in the characteristics of the research subjects and the intraoperative data of the two groups. Therefore, it could be inferred that the two groups were homogeneous.

Table 1. Characteristics of subjects

\begin{tabular}{|c|c|c|c|}
\hline Variables & $\begin{array}{c}\begin{array}{c}\text { OPCAB } \\
n=35\end{array} \\
\end{array}$ & $\begin{array}{c}\text { TCABG } \\
n=74\end{array}$ & p-value \\
\hline Age, year, median (min-max) & $58(41-67)$ & $57(40-74)$ & 0,642 \\
\hline Female, n (\%) & $2(5,7 \%)$ & $14(18,9 \%)$ & 0,069 \\
\hline Diabetes mellitus, $\mathrm{n}(\%)$ & $11(31,4 \%)$ & $37(50,0 \%)$ & 0,068 \\
\hline Hypertension, n (\%) & $14(40,0 \%)$ & $36(48,6 \%)$ & 0,398 \\
\hline Smoking, $n(\%)$ & $(34,3 \%)$ & $24(32,4 \%)$ & 0,848 \\
\hline Dysilipidemia, n (\%) & $4(11,4 \%)$ & $15(20,3 \%)$ & 0,256 \\
\hline Chronic renal disease & $6(17,1 \%)$ & $7(9,5 \%)$ & 0,248 \\
\hline Preoperative stroke, n (\%) & 0 & $2(1,4 \%)$ & $\mathrm{Na}$ \\
\hline Preoperative EF, mean (SD) & $2.4,60(4,08)$ & $23.59(4,72)$ & 0,702 \\
\hline SSS, mean (SD) & $\Xi 0,60(6,33)$ & $32,07(7,37)$ & 0,699 \\
\hline SRS, mean (SD) & $2.5,74(6,79)$ & $27,34(7,31)$ & 0,422 \\
\hline SDS, median (min-ma & $5(2-8)$ & $5(1-8)$ & 0,836 \\
\hline Ischemic burden, median (min-max) & $6,0(3-10)$ & $6,0(1,25-10)$ & 0,782 \\
\hline
\end{tabular}

Note: Description: EF: ejection fraction; OPCAB: off-pump coronary artery bypass; TCABG: conventional coronary artery bypass; SSS: summed stress score; SRS: summed rest score; SDS: summed different score; SD: standard deviation; IABP: intra-aortic ballon pump; CPB: cardiopulmonary bypass

Based on the data in this study, the median (min-max) age of the patients with the OPCAB procedure compared to that of those with the TCABG procedure was not statistically significant [58 (41-67) years vs 57 (40-74) years, respectively; $P=0.642]$.

\section{Intraoperative Data of Patients}

The intraoperative data as provided in Table 2 revealed that pre-installed IABP was not significantly different in the 
two groups. In this regard, $57.1 \%$ was installed in the OPCAB group, whereas $62.2 \%$ in the TCABG group, with $p=0.617$. In this study, $26.3 \%$ of the OPCAB group were patients with "Left Main Disease" compared to $30.9 \%$ of the TCABG group, where these figures were not significantly different, with $p=0.612$. For each group, the median number of anastomosed vessel was $3(2-4)$ in the OPCAB group vs. $3(2-5)$ in the TCABG group, where these values too were statistically insignificant, with $p=0.157$. The intraoperative data of the two groups were also homogeneous because they were not statistically significant.

Table 2. Intraoperative data

\begin{tabular}{|c|c|c|c|}
\hline Variables & $\begin{array}{c}\text { OPCAB } \\
n=35\end{array}$ & $\begin{array}{c}\text { TCABG } \\
n=74\end{array}$ & p-value \\
\hline IABP preincision, $\mathrm{n}(\%)$ & $20(57,1 \%)$ & $46(62,2 \%)$ & 0,617 \\
\hline Left Main, & $10(26,3 \%)$ & $25(30,9 \%)$ & 0,612 \\
\hline Total graft, median (min-max) & $3(2-4)$ & $3(2-5)$ & 0,157 \\
\hline $\begin{array}{l}\text { Aortic cross clamp duration, } \\
\text { median (min -max) }\end{array}$ & & $53,0(24-197)$ & - \\
\hline CPB duration, median (min-max) & - & $88(42-223)$ & - \\
\hline
\end{tabular}

Note: OPCAB: off-pump coronary artery bypass; TCABG: conventional coronary artery bypass; IABP: intra-aortic ballon pump; CPB: cardiopulmonary bypass.

\section{Postoperative Data of Patients}

The length of stay in the hospital as given in Table 3 was statistically significantly lower after the OPCAB procedure than after the TCABG procedure, at 6 (4-27) days and 10 (1-35) days respectively, with $p$-value $<0.001$. This is generally caused by the fact that the incidence of morbidity was relatively lower in the OPCAB group than in the TCABG group.

Table 3. Postoperative outcome during treatment

\begin{tabular}{lccc}
\hline \multicolumn{1}{c}{ Variables } & $\begin{array}{c}\text { OPCAB } \\
\mathbf{n}=\mathbf{3 5}\end{array}$ & $\begin{array}{c}\text { TCABG } \\
\mathbf{n}=\mathbf{7 4}\end{array}$ & p-value \\
\hline IABP: & $1(2,9 \%)$ & $9(12,2 \%)$ & 0,094 \\
$\quad$ Intraoperative, $\mathrm{n}(\%)$ & 0 & $5(5,4 \%)$ & \\
$\quad$ Postoperative, $\mathrm{n}(\%)$ & 36,53 & $35,0(17-45)$ & 0,217 \\
Postoperative EF \%, & $(22-48)$ & & \\
median (min-max) & $6(4-27)$ & $10(1-35)$ & $<0,001$ \\
\hline
\end{tabular}

Note: Abbreviation: EF: ejection fraction; OPCAB: off-pump coronary artery bypass; TCABG: conventional coronary artery bypass; SD: Standard deviation; IABP: intra-aortic ballon pump.

\section{Morbidity and Mortality during Treatment}

The morbidity during treatment was $25.7 \%$ in the OPCAB group compared to $51.4 \%$ in the TCABG group, which means that they were statistically significantly different ( $R R=3.55 ; 95 \% \mathrm{Cl}=1.40-8.91 ; \mathrm{p}=0.012$ ). In this case, the statistically significant morbidities included arrhythmias, renal failure, and postoperative stroke. As regards with arrhythmias, they reached $8.6 \%$ in the OPCAB group and $39.2 \%$ in the TCABG group, thus producing statistically significant results ( $R R=6.13 ; 95 \% \mathrm{Cl}=1.71-21.92 ; \mathrm{p}=0.001)$ with the statistical power standing at 91.7\%. Another morbidity with statistically significant results stemmed from postoperative acute renal failure where the OPCAB group stood at $8.6 \%$ compared to the TCABG group at $27 \%$
( $R R=3.96 ; 95 \% \mathrm{Cl}=1.09$ - 14.35; $\mathrm{p}=0.027$ ). Postoperative outcomes with statistically significantly different results were also found in the incidence of stroke. In relation to this, the OPCAB group saw $2.9 \%$, while the TCABG group witnessed $17.6 \%(R R=7.25 ; 95 \% \mathrm{Cl}=1.91-57.81 ; p=0.032)$. Neurological dysfunction after CABG procedures can manifest as stroke, encephalopathy, delirium, and postoperative cognitive dysfunction (7). (8).

Table 4. Postoperative morbidity and mortality during treatment

\begin{tabular}{crrrrr}
\hline Variables & $\begin{array}{c}\text { OPCAB } \\
\mathbf{n = 3 5}\end{array}$ & $\begin{array}{c}\text { TCABG } \\
\mathbf{n = 7 4}\end{array}$ & $\begin{array}{c}\boldsymbol{p} \text { - } \\
\text { value }\end{array}$ & $\mathbf{R R}$ & Cl 95\% \\
\hline Morbidity: & $9(25,7 \%)$ & $38(51,4 \%)$ & 0,012 & 3,55 & $1,40-8,91$ \\
Arrythmia & $3(8,6 \%)$ & $29(39,2 \%)$ & 0,001 & 6,13 & $1,71-21,92$ \\
Stroke & $1(2,9 \%)$ & $13(17,6 \%)$ & 0,032 & 7,25 & $1,91-57,81$ \\
Infarct & $1(2,9 \%)$ & $5(6,8 \%)$ & 0.662 & 2,46 & $0,28-21,93$ \\
Redo surgery & $1(2,9 \%)$ & $4(5,4 \%)$ & 1 & 1,94 & $0,21-18,06$ \\
Renal failure & $3(8,6 \%)$ & $20(27,0 \%)$ & 0,027 & 3,96 & $1,09-14,35$ \\
LCOS & $4(11,4 \%)$ & $14(18,9 \%)$ & 0,325 & 1,81 & $0,55-5,97$ \\
Sepsis & $2(5,7 \%)$ & $16(21,6 \%)$ & 0,037 & 4,55 & $0,99-21,04$ \\
Mortality & $2(5,7 \%)$ & $12(16,2 \%)$ & 0,126 & 3,20 & $0,67-15,12$ \\
\hline
\end{tabular}

Note: Abbreviation: OPCAB: off-pump coronary artery bypass; TCABG: conventional coronary artery bypass; SD: standard deviation; LCOS: low cardiac output syndrome.

\section{DISCUSSION}

Unlike the OPCAB technique, the TCABG technique is performed using a CPB machine that provides hemodynamic support for patients, allowing surgeons to manipulate the heart as needed without impairing their hemodynamic stability. However, the use of the CPB machine is related to the activation of the inflammatory system and has the potential to induce the failure of various organs after surgery. On the other side, the OPCAB technique has the advantage of limiting ischemia only to anastomosed coronary arteries which will reduce myocardial injury to provide better postoperative outcomes (8).

The length of stay in the hospital was statistically significantly lower after the OPCAB procedure than after the TCABG procedure. Generally, the incidence of morbidity is lower in the OPCAB group than in the TCABG group. This is supported by Elmahrouk, et al. (2018), who reported that the length of stay after the OPCAB procedure was lower than that after the TCABG procedure $(9.8 \pm 5.6$ and $12.86 \pm 9.86$ days respectively, with $p$-value $<0.001)$, showing significance in statistical difference (9).

In this research found that the morbidity during treatment in the OPCAB group lower than in the TCABG group. The morbidities were sourced from arrhythmias, renal failure, and postoperative stroke. Atrial fibrillation becomes the most common complication after cardiac surgery, affecting $10 \%$ to $40 \%$ of patients post CABG procedures. These arrhythmias occur most often in the first five days of the postoperative period, ranging from 24 to 72 hours, but they rarely come to happen after the first week (10).

Another complication in this study was postoperative acute renal failure which occurred at a lower rate after the OPCAB procedure. There is no comprehensive mechanism to explain kidney failure associated with heart surgery. It is thought to be the result of a complex interaction between a number of related factors. Clinical variables related to renal ischemia caused by arteriosclerosis and decreased cardiac 
output, hypotension, and hypoperfusion are the most influential perioperative risk factors. Reservation of kidney failure in the TCABG group is supported by the findings of the literature showing that patients undergoing CABG procedures with the CPB machine have a higher risk of developing acute kidney failure due to decreased perfusion, absence of pulsatile flow, excessive hemolysis, aggregate embolization platelets, and fibrin (11). The OPCAB technique without using the CPB machine is estimated to reduce the occurrence of acute postoperative kidney failure. This statement is in accordance with the CORONARY research reporting that the OPCAB technique significantly reduces acute kidney injury. In a meta-analysis of a subgroup of 1,571 patients from 25 trials, Deppe et al. showed the OPCAB technique to reduce the risk of kidney dysfunction by $2.1 \%$ (OR, 0.79 ; 95\% Cl: $0.71-0.89 ; p=0.0001)$. In contrast to this, the ROOBY study reported no statistically significant difference between $O P C A B$ and TCABG for kidney failure requiring dialysis (6).

Postoperative outcomes which produced statistically significantly different results were also found in the incidence of stroke. In this case, the occurrence of it after the OPCAB procedure was lower than after the TCABG procedure. Neurological dysfunction after CABG procedures can manifest as stroke, encephalopathy, delirium, and postoperative cognitive dysfunction (8). Perioperative stroke is defined as a temporary or permanent, focal or global neurological deficit that occurs within 30 days after surgery or in hospital care. Prolonged reversible ischemic neurological deficits are defined as events lasting $>24$ hours. All stroke results included in this study were examined by a neurologist and diagnosed with a computed tomography (CT-scan) of the head used for assessment of lesions, which were further confirmed by a radiology specialist (12).

In a multicenter prospective study of more than 2,000 patients, ascending aortic atherosclerosis is the strongest independent predictor of stroke associated with CABG procedures (13). Atheromatous flake embolization from the aorta may take place during aortic cannulation to connect to the CPB machine, when aortic cross clamps are installed or removed or when site aortic biting is utilized in proximal conduit anastomosis (14). Cerebral hypoperfusion can be worsened by carotid artery stenosis. In general, observational studies consistently suggest that the OPCAB procedure can reduce the risk of stroke, but this relationship has not been confirmed in a

\section{REFERENCES}

1. Bonow RO, Maurer G, Lee KL, et al. Myocardial Viability and Survival in Ischemic Left Ventricular Dysfunction. The New England Journal of Medicine. 2011; 364(17): 1617-1625.

2. Farzaneh-Far A and Borges-Neto S. Ischemic Burden, Treatment Allocation, and Outcomes in Stable Coronary Artery Disease. Circulation: Cardiovascular Imaging. 2011; 4(6): 746-753.

3. Elsaban K, Alsakhri H, Al-Rashidy A, and Wahdan M. Differentiation between Clinical and Academic Myocardial Viability. Complementary Myocardial Perfusion SPECT and Low Dose Dobutamine Echocardiography Role VS. Histopatological Study. few randomized controlled trials (15). In an analysis involving more than 42,000 patients, there was a $35 \%$ reduction in stroke risk in patients with the OPCAB technique compared with the TCABG technique. The CABG off or on pump revascularization study (CORONARY) demonstrated no statistically significant difference between TCABG and OPCAB in stroke rates. Similar results were also observed in two recently published clinical trials: German off-pump coronary artery bypass grafting in elderly patients (GOPCABE) and the PRAGUE 6 trial. Several meta-analyses that had been conducted led to controversial results (8). Based on a meta-analysis conducted by Afilalo, et al., which was reported in 59 randomized controlled studies with 8,961 patients, the risk of stroke was lower after 30 days of the OPCAB technique than of the TCABG technique (16). In contrast, a metaanalysis by Moller et al. involving 86 randomized controlled studies of 10,716 patients showed statistically insignificant results in the risk of stroke in the long-term evaluation. Evaluation of different time points, selection of studies, and different methodologies explain the different results of various previous studies (17).

Although this research method is a retrospective analysis without random studies using medical record data, which caused some samples to be excluded due to data incompleteness, it is found that the samples of both groups remain homogeneous to reduce selection bias. This study has several limitations. One of them is the evaluation of postoperative outcomes which were only assessed during hospitalization. In fact, medium-term and long-term evaluations must be conducted to examine whether the OPCAB technique is better than the TCABG technique in terms of comparative survival, such as re-treatment in hospital, interventions reset, and quality of life. Another limitation is that these types of CABG procedures were not carried out by the same operator. The admission of patients to either of the groups was not random, but it was decided by the choice of the operator.

There were statistically significant differences in the occurrence of morbidities, including arrhythmias, kidney failure, and postoperative stroke, between CAD patients with $\mathrm{EF} \leq 30 \%$ and ischemic burden $\leq 10 \%$ who underwent the OPCAB surgery and patients who underwent the TCABG surgery. Mortality was lower in patients with $\mathrm{EF} \leq 30 \%$ and ischemic burden $\leq 10 \%$ after the OPCAB procedure than after the TCABG procedure, despite the fact that the difference was not statistically significant.

Journal of Nuclear Medicine and Radiation Therapy. 2017; 8(5): 1-12.

4. Inamdar AK, Shende SP, and Inamdar SA. Outcome of Coronary Artery Bypass Graft Surgery in Patients with Low Ejection Fraction. Medical Journal of Dr. D. Y. Patil Vidyapeeth. 2017; 10: 162-166.

5. Maltais S, Ladouceur $\mathrm{M}$, and Cartier R. The Influence of a Low Ejection Fraction on Long-Term Survival in Systematic Off-Pump Coronary Artery Bypass Surgery. European Journal of Cardio-thoracic Surgery. 2011; 39(5): e122-127.

6. Fudulu D, Benedetto $U$, Pecchinenda GG, et al. Current Outcomes of Off-Pump Versus On-Pump Coronary Artery Bypass Grafting: Evidence from 
Randomized Controlled Trials. Journal of Thoracic Disease. 2016; 8(10): S758-771.

7. Palmerini T, Savini C, and Eusanio MD. Risk of Stroke after Coronary Artery Bypass Graft - Recent Insights and Perspectives. Interventional Cardiology. 2014; 9(2): 77-83.

8. Raslan S, ElDesoky M, Karam G, Hanoura S, and Elrakhawy HM. Hemodinamic Changes during OffPump Coronary Artery Bypass Graft. Al-Azhar Medical Journal. 2011; 40(4): 879-888.

9. Elmahrouk AF, Hamouda TE, Kasab I, Ismail MF, and Jamjoom AA. Short Term Outcome of Conventional Versus Off-Pump Coronary Artery Bypass Grafting For High-Risk Patients. Journal of the Egyptian Society of Cardio-Thoracic Surgery. 2018; 26(1): 57-63.

10. Júnior MSB, Matkovski PD, Giovanni FJD, Fenili R, Varella EL, and Dietrich A. Incidence of Postoperative Atrial Fibrillation in Patients Undergoing On-Pump and Off-Pump Coronary Artery Bypass Grafting. Revista Brasileira de Cirurgia Cardiovascular. 2015; 30(3): 316-324.

11. Schopka S, Diez C, Camboni D, Floerchinger B, Schmid C, and Hilker M. Impact of Cardiopulmonary Bypass on Acute Kidney Injury Following Coronary Artery Bypass Grafting: Matched Pair Analysis. J Cardiothoracic Surgery. 2014; 9(1): 1-7.

12. Hornero F, Martín E, Rodríguez R, et al. Off-Pump
Surgery in Preventing Perioperative Stroke after Coronary Artery Bypass Grafting: A Retrospective Multicenter Study. European Journal of Cardiothoracic Surgery. 2013; 44(4): 725-731.

13. Bergman $P$ and Linden J. Atherosclerosis of the Ascending Aorta as a Major Determinant of the Outcome of Cardiac Surgery. Nature Clinical Practice Cardiovascular Medicine. 2005; 2: 246-251

14. Emmert MY, Grünenfelder J, Scherman J, et al. HEARTSTRING Enabled No-Touch Proximal Anastomosis For Off-Pump Coronary Artery Bypass Grafting: Current Evidence and Technique. Interact Cardiovasc Thorac Surg. 2013; 17(3): 538-541.

15. Naylor AR, Mehta Z, Rothwell PM, and Bell PR. Carotid Artery Disease and Stroke during Coronary Artery Bypass: A Critical Review of the Literature. European Journal of Vascular and Endovascular Surgery. 2002; 23(4): 283-294.

16. Afilalo J, Rasti M, Ohayon SM, Shimony A, and Eisenberg MJ. Off-Pump VS. On-Pump Coronary Artery Bypass Surgery: An Updated Meta-Analysis and Meta-Regression of Randomized Trials. European Heart Journal. 2012; 33(10): 1257-1267.

17. Møller CH, Penninga L, Wetterslev J, Steinbrüchel DA, and Gluud C. Off-Pump Versus On-Pump Coronary Artery Bypass Grafting for Ischaemic Heart Disease. Cochrane Database Syst Rev. 2012; 3: 1-7. 